\title{
Physicochemical characteristics, phenolic profile, and antioxidant capacity of Syrah tropical wines: effects of vineyard management practices
}

\author{
Erika Samantha Santos de Carvalho ${ }^{\mathrm{a}}$, Aline Camarão Telles Biasoto $\mathrm{b}^{*}$, \\ Rita de Cássia Mirela Resende Nassur ${ }^{\mathrm{c}}$, Ana Paula André Barros ${ }^{\mathrm{d}}$, \\ Patrícia Coelho Souza Leão ${ }^{\mathrm{b}}$, Renan da Silva Lima ${ }^{\mathrm{e}}$, Adriano Costa de Camargo ${ }^{\mathrm{f}^{*}}$ \\ and Maria Eugênia de Oliveira Mamede ${ }^{a}$
}

\begin{abstract}
aUniversidade Federal da Bahia-UFBA, Departamento de Análises Bromatológica Faculdade de Farmácia-Salvador-BA, Brasil
bEmpresa Brasileira de Pesquisa Agropecuária-Embrapa Semiárido, Rodovia BR 428, Km 152, Caixa Postal 23. CEP. 56.302-970 Petro-

lina-PE, Brasil

${ }^{c}$ Universidade do Estado da Bahia-UNEB, Av. Edgard Chastinet, s/n-Campus Juazeiro, Juazeiro-BA, Brasil

dInstituto Federal de Educação, Ciência e Tecnologia do Sertão Pernambucano-Campus Petrolina Zona Rural-Petrolina-PE, Brasil

eDepartment of Biochemistry, Memorial University of Newfoundland, St. John's, NL, A1B 3X9, Canada

fDepartamento de Ciencias Vegetales, Facultad de Agronomía e Ingeniería Forestal, Pontificia Universidad, Católica de Chile, Casilla 30622, Santiago, Chile

*Corresponding author: Aline Camarão Telles Biasoto, Empresa Brasileira de Pesquisa Agropecuária-Embrapa Semiárido, Rodovia BR 428, Km 152, Caixa Postal 23. CEP. 56.302-970 Petrolina-PE, Brasil. E-mail: aline.biasoto@embrapa.br; Adriano Costa de Camargo, Departamento de Ciencias Vegetales, Facultad de Agronomía e Ingeniería Forestal, Pontificia Universidad, Católica de Chile, Casilla 306-22, Santiago, Chile. E-mail: adrianoesalq@gmail.com
\end{abstract}

DOI: $10.31665 / J F B .2020 .9220$

Received: March 17, 2020; Revised received \& accepted: March 31, 2020

Citation: de Carvalho, E.S.S, Biasoto, A.C.T, de Cássia Mirela Resende Nassur, R., Barros, A.P.A., Leão, P.C.S, Lima, R.S., de Camargo, A.C., and de Oliveira Mamede, M.E. (2020). Physicochemical characteristics, phenolic profile, and antioxidant capacity, of Syrah tropical wines: effects of vineyard management practices. J. Food Bioact. 9: 70-78.

\begin{abstract}
The present study evaluated the influence of training systems and rootstocks on the quality of Syrah tropical wines, produced at São Francisco Valley, Brazil. For this purpose, physicochemical characteristics, phenolic composition, and antioxidant activity were assessed in wines produced with grapes grown under divided trellis system (lyre) and esparlier or vertical shoot position (VSP) training systems, grafted on IAC 572, IAC 766 and Paulsen 1103 rootsotcks and harvested at two different periods. Harvest season had the strongest influence on wine quality, followed by the rootstock. Regardless of the training system and climatic variability between the harvests, the use of the IAC 766 rootstock led to wines with higher alcohol, anthocyanins contents and color intensity. The interaction between the espalier training system and the rootstock IAC 766 resulted in higher flavonol content, phenolic acids, and malvidin-3-O-glucoside, which was detected as the major phenolic as quantified by HPLC. This wine also presented significant levels of procyanidins A2 and B2, which showed a positive correlation with the antioxidant activity.
\end{abstract}

Keywords: São Francisco Valley; Vitis vinifera L; Phenolic compounds; Antioxidant activity; Physicochemical composition. 


\section{Introduction}

Wine consumption has long been related to a myriad of healthpromoting effects, such as lower incidence of some types of cancer and cardiovascular ailments (Forester and Waterhouse, 2009). The impact of wine components on health continue to be assessed by many studies, and it seems to be associated with the presence of antioxidant substances, namely phenolic compounds (Cueva et al., 2016; Fernandes et al. 2017). Phenolics are plant secondary metabolites capable of mitigating oxidative stress mainly through free radical scavenging, reducing properties as well as metal chelation (Shahidi and Ambigaipalan, 2015).

Wine possesses a great variety of phenolic groups, namely phenolic acids and flavonoids, including anthocyanins and proanthocyanidins (de Oliveira et al., 2017). Additionally, phenolic-rich extracts from winemaking by-products have displayed in vitro inhibition of copper-induced human LDL-cholesterol oxidation, as well as prevention of peroxyl radical-induced DNA strand scission, which is believed to be related to their antioxidant capacity (de Camargo et al., 2014).

Grape cultivation practices play an important role in wine's phenolic composition, and, consequently, the health-promoting benefits associated with these compounds (Sartor et al., 2017). The recently established wine production in São Francisco Valley, Brazil, has been gaining attention due to the product's unique characteristics. The region is located in an area of a semiarid tropical climate, in the Brazilian Northeast (latitude of $8^{\circ}$ South, longitude of $40^{\circ}$ West, and altitude of $350 \mathrm{~m}$ ). São Francisco Valley has an annual average temperature of $26^{\circ} \mathrm{C}$, insolation of $3,000 \mathrm{~h} /$ year, and maximum rainfall of $500 \mathrm{~mm}^{3} /$ year (Padilha et al., 2016). Due to the absence of low temperatures during the autumn and winter seasons and the availability of water for irrigation, year-round production can be carried out, with two annual harvests. Currently, the wine production in São Francisco Valley accounts for about 4 million liters per year, being majorly destined to sparkling wines manufacture $(70 \%)$ (Pereira et al., 2016). Unlike other Brazilian wine regions, São Francisco Valley wines, which are classified as tropical wines, are mainly produced from Vitis vinifera L. grapes, being Syrah the main variety.

However, as grape production for winemaking in São Francisco is still recent, all the optimum agricultural practices for the grape varieties grown in this area have not been totally established thus far. In some cases, the grapes used for winemaking are cultivated using the same practices used to produce table grapes. Techniques applied to vines grown in temperate climate conditions have also been applied. However, neither approach is consistent with the correct cultivation practices for tropical winemaking grapes. The production of quality wines is directly related to the climatic conditions of the vineyard and the agronomic techniques adopted, including the choice of vine rootstock and training system. Some studies have highlighted the relevance of climatic conditions, geographic origin, and crop management practices for wine quality (Alañón et al., 2015; Cassino et al., 2017; Moreno et al., 2017).

A suitable training system favors microclimatic conditions, such as appropriate balance for the vegetative growth of grapevine, increased production, and maximized oenological potential of the grapes (Santos et al., 2006). However, the effect of grapevine grafting on wine composition remains controversial, since other variables such as cultivar and environment may affect the resulting performance (Nassur et al., 2017). Among the adopted management systems in traditional wine-producing areas, the vertical shoot position system is considered the most suitable for Vitis vinifera grapes (Miele and Mandelli, 2014). Vertical and oblique systems, such as espalier and lyre, promote bunches exposure and aeration between the lines, making the microclimate warmer and less humid, which favors grape maturation and reduces rot occurrence (Regina et al., 1998). In addition, the divided trellis system (e.g., lyra) almost doubles grape yield when compared to the VSP system (Carbonnea et al., 2007). Nevertheless, the rootstock influences the plant vegetative growth, yield, and grape quality ( $\mathrm{Li}$ et al., 2019), with significant soil-climatic interference, responding differently according to the grafted canopy variety (Nassur et al., 2014).

With that being said, the study of more suitable techniques for the agronomic management of Syrah vines cultivated under semi-arid tropical climate conditions may play a role in improving the quality of red wine produced in São Francisco Valley, Brazil. Therefore, the objective of this study was to evaluate the effect of different rootstocks and training systems on the physicochemical parameters, phenolic composition, and antioxidant activity of Syrah red wines from the São Francisco Valley.

\section{Material and methods}

\subsection{Chemicals}

Phenolic standards ferulic, syringic, chlorogenic, caffeic acids, and quercetin were obtained from Chem Service (WestChester, USA) and Sigma-Aldrich (St Louis, MO, USA), while the other standards were purchased from Extrasynthese (Genay, France). Orthophosphoric acid was obtained from Fluka (Switzerland), and HPLC grade acetonitrile was purchased from JT Baker (Phillipsburg, NJ, USA).

\subsection{Grape cultivation}

Grapes of the Syrah variety were harvested from 'Bebedouro' experimental field-Embrapa Semiarid $\left(09^{\circ} 09^{\prime} \mathrm{S}, 40^{\circ} 22^{\prime} \mathrm{W}, 365.5 \mathrm{~m}\right.$, Petrolina-PE, Brazil) in June 2014 (harvest I) and December 2014 (harvest II), corresponding to the $5^{\text {th }}$ and $6^{\text {th }}$ production cycles, respectively. The treatments in the field were arranged in subdivided plots, where two training systems represented the main treatments: divided trellis (lyre) and vertical shoot position (VSP), and the secondary treatments by three rootstocks (Paulsen 1103, IAC 572, and IAC 766). The experimental design was a randomized block with four replicates. During the crop year, the climatic conditions presented the following means and deviations: temperature (26.2 $\left.\pm 0.9{ }^{\circ} \mathrm{C}\right)$, relative humidity $(64.4 \pm 5.5 \%)$, precipitation $(549.8$ $\pm 181.8 \mathrm{~mm})$, solar brightness $(7.5 \pm 1.1$ hours $)$, solar radiation $\left(442.3 \pm 32.3 \mathrm{~W} \mathrm{~m}^{2}\right)$, and air velocity $\left(190.4 \pm 27.2 \mathrm{~km} \mathrm{day}^{-1}\right)$.

\subsection{Winemaking}

After manual harvesting, $40 \mathrm{~kg}$ of grapes (four replicates of each treatment in the experimental area) were homogenized and experimentally vinified at the Embrapa Semi-Arid Oenology Laboratory, Petrolina-PE, Brazil. Vinification was carried out in duplicate based on the traditional method for young red wines (Peynaud, 1997). After destemming and crushing the grapes, the wort must placed in $20 \mathrm{~L}$ glass bottles, capped with a glass airlock valve, and sulfided with the addition of potassium metabisulphite (100 $\left.\mathrm{mg} \mathrm{kg}^{-1}\right)$. The alcoholic fermentation was carried out in an airconditioned room $\left(25 \pm 1^{\circ} \mathrm{C}\right)$, followed by 7 -day maceration after 
addition of yeast Saccharomyces cerevisiae Maurivin PDM ${ }^{\circledR}(200$ $\left.\mathrm{mg} \mathrm{Kg}{ }^{-1}\right)$, ammonium phosphate activator Gesferm Plus ${ }^{\circledR}(200$ $\left.\mathrm{mg} \mathrm{Kg}{ }^{-1}\right)$, and Everum Thermp pectinolytic enzyme $(0.008 \mathrm{~mL}$ $\left.\mathrm{Kg}^{-1}\right)$. Then, spontaneous malolactic fermentation $\left(18 \pm 1{ }^{\circ} \mathrm{C}\right)$, cold tartaric stabilization $\left(0{ }^{\circ} \mathrm{C}\right)$, and the addition of a stabilizer composed of Arabic gum and metatartaric acid-Stabigum ${ }^{\circledR}(400$ $\mathrm{mg} \mathrm{L}^{-1}$ ) were performed. Before bottling, the free sulfur dioxide $\left(\mathrm{SO}_{2}\right)$ content of the wines was corrected to $50 \mathrm{mg} \mathrm{L}^{-1}$, and the wines were stored in an air-conditioned wine cellar at $18 \pm 1{ }^{\circ} \mathrm{C}$ one month before the analyses were carried out.

\subsection{Physicochemical analyses}

The physicochemical parameters were determined following the OIV (2015) procedures. The $\mathrm{pH}$ of each sample was measured using a $\mathrm{pH}$ meter Tec-3MP (TECNAL, Piracicaba, SP, Brazil). After the simple distillation of the samples in SuperDee automatic distiller (Gibertini, Italy), the alcohol content and the dry extract content in Super Alcomat electronic hydrostatic balance (Gibertini, Italy) were determined at $20{ }^{\circ} \mathrm{C}$. The total acidity was quantified by titration of the samples with $0.1 \mathrm{~N} \mathrm{NaOH}$ to $\mathrm{pH}$ 8.2. The volatile acidity was determined after the steam distillation of the samples in the SuperDee distiller and titration with $0.1 \mathrm{~N} \mathrm{NaOH}$. The free and total sulfur dioxide contents were determined by iodometry according to the Ripper method, which uses a $0.02 \mathrm{~N}$ iodine solution as titrant and starch as an indicator. The content of total reducing sugars was determined by the Lane-Eynon method, based on the procedures described by Ribéreau-Gayon et al. (2006).

\subsection{Phenolic composition, color intensity, and antioxidant capacity}

The total phenolic content (TPC) was determined by the FolinCiocalteu method (Singleton and Rossi, 1965). Absorbance reading was performed on a Genesys ${ }^{\mathrm{TM}} 10 \mathrm{~S}$ UV-VIS spectrophotometer (Thermo Fisher Scientific, Waltham, MA, USA) and a standard curve was prepared using gallic acid. The concentration of total monomeric anthocyanins was determined spectrophotometrically by the method described by Lee et al. (2005). Monomeric anthocyanin contents were expressed as malvidin-3-O-glucoside equivalent (MGE). The color intensity (CI) was determined from the sum of the absorbance readings at $420 \mathrm{~nm}, 520 \mathrm{~nm}$ and $620 \mathrm{~nm}$ (Ough and Amerine, 1988), and the antioxidant capacity was evaluated by the DPPH method (2,2-diphenyl-1-picryl-hydrazyl) according to the procedure described by Brand-Williams et al. (1995), using Trolox (6-hydroxy-2,5,7,8-tetramethylchromate-2-carboxylic acid) to prepare the standard curve.

\subsection{Identification and quantification of phenolic compounds}

Phenolic compounds were identified and quantified by high-performance liquid chromatography (HPLC) using a Waters 2695 Alliance system (Milford, MA, USA) equipped with DAD-array and FD-fluorescence detectors working simultaneously using a validated method described elsewhere (Natividade et al., 2013).

\subsection{Statistical analysis}

The Statistical analysis was carried out using the SAS software (SAS ${ }^{\circledR}$ Institute Inc, Cary, NC, 2015). Results were submitted to
ANOVA and means compared by Tukey's test $(\mathrm{p} \leq 0.05)$. Principal Component Analysis (PCA) and Pearson's correlation analyses were also performed.

\section{Results and discussion}

\subsection{Physicochemical characteristics}

The physicochemical characteristics of the wines are presented in Table 1 . The $\mathrm{pH}$ value of the wines varied slightly between the evaluated harvests, from 3.77 to 3.96 for the harvest I (June) and from 3.70 to 3.90 for the harvest II (December). According to Jackson (2008), the ideal $\mathrm{pH}$ for red wines should be between 3.3 and 3.6. However, due to the intense solar radiation in the São Francisco Valley and the high levels of potassium in the soil, the red wines of this region usually have higher $\mathrm{pHs}$, reaching values as high as 4.0. Padilha et al. (2016) evaluated commercial red wines and observed $\mathrm{pH}$ values between 3.60 and 4.09. The influence of the training system on $\mathrm{pH}$ was significant $(\mathrm{p} \leq 0.05)$ only for samples from grapes grown under the IAC 766 rootstock from harvest II (lower $\mathrm{pH}$ value). Reduced $\mathrm{pH}$ in wines can be associated with higher color intensity and phenolic compounds concentration (Piccardo et al., 2019). Grape pulp usually ripens faster than skins, reducing $\mathrm{pH}$ and sugar content in the must and results in high $\mathrm{pH}$ and sugar concentrations in the must (Llaudy et al., 2008) and wine. The period of the year and the rootstock can influence ripening and quality attributes in wines.

The total titratable acidity (TTA) ranged from 5.20 to $6.55 \mathrm{~g}$ $\mathrm{L}^{-1}$ in wines from harvest I and 4.03 and $4.63 \mathrm{~g} \mathrm{~L}^{-1}$ in wines from harvest II (Table 1). Different TTA values between harvests could be due to the higher degree of grape maturation during the harvest II period. The Brazilian legislation (Brasil, 2010) establishes that the TTA content of red wines should be between 55 and 130 $\mathrm{mEq} \mathrm{L}^{-1}$ (4.12 to $9.75 \mathrm{~g} \mathrm{~L}^{-1}$ ) and, in general, the evaluated wines followed this specification, except for harvest II wines. For both harvests, the training system did not promote a significant difference in TTA. The Paulsen 1103 rootstock resulted in wines with the highest TTA, considering the ones produced from harvest I. The same was observed for rootstock IAC 572 in harvest II. TTA values reported by Andrade et al. (2008) in red wines from the São Francisco Valley ranged from 3.6 to $6.3 \mathrm{~g} \mathrm{~L}^{-1}$, similar to what was found in the present study, demonstrating that lower TTAs is a characteristic of wines produced in this location. According to Ordunã (2010), lower TTAs are correlated to higher $\mathrm{pH}$ in grapes, which is influenced by the potassium concentration. Higher temperatures, such as the ones recorded in the São Francisco Valley during fruit maturation, can significantly increase the potassium level in the fruit. Lima et al. (2015) also stated that the high temperatures and luminosity in this area could lead to an acidity decrease, with higher $\mathrm{pH}$ values.

The alcohol content of the wines ranged from 10.50 to $11.14 \%$ (v/v) for the harvest I and 12.11 to $13.40 \%(\mathrm{v} / \mathrm{v})$ for the harvest II. The increased alcohol content in harvest II may be the result of a higher degree of grape maturation, which, consequently generates a higher content of total soluble solids, mostly sugars. Regardless of the training system, the IAC 766 rootstock resulted in wines with the highest alcoholic content for the harvest I, with no significant differences concerning the rootstock in harvest II for the majority of samples. Miele and Rizzon (2019) suggested that alcohol content is one of the variables most affected by the rootstocks system in Cabernet Sauvignon wines.

The dry extract concentration of the wines ranged from $24.70 \mathrm{~g}$ 
Table 1. Physicochemical characteristics, total phenolic content, total monomeric anthocyanin content, and antioxidant activity of Syrah tropical wines from grapes with different training systems and rootstocks

\begin{tabular}{|c|c|c|c|c|c|c|c|}
\hline \multirow{3}{*}{ Parameter } & \multirow{3}{*}{ Training systems ${ }^{1}$} & \multicolumn{6}{|c|}{ Rootstock $^{2}$} \\
\hline & & Paulsen 1103 & IAC-766 & IAC-572 & Paulsen 1103 & IAC-766 & IAC-572 \\
\hline & & \multicolumn{3}{|c|}{ June, 2014 (Harvest I) } & \multicolumn{3}{|c|}{ December, 2014 (Harvest II) } \\
\hline \multirow[t]{2}{*}{$\mathrm{pH}$} & Lyre & $3.77 \mathrm{~A}^{\mathrm{c}}$ & $3.93 \mathrm{~A}^{\mathrm{a}}$ & $3.85 \mathrm{~A}^{\mathrm{b}}$ & $3.83 \mathrm{~A}^{\mathrm{a}}$ & $3.79 A^{b}$ & $3.80 \mathrm{~A}^{\mathrm{a}}$ \\
\hline & VSP & $3.79 A^{b}$ & $3.96 \mathrm{~A}^{\mathrm{a}}$ & $3.94 \mathrm{~A}^{\mathrm{a}}$ & $3.83 \mathrm{~A}^{\mathrm{a}}$ & $3.70 \mathrm{~B}^{\mathrm{b}}$ & $3.90 \mathrm{~A}^{\mathrm{a}}$ \\
\hline \multirow[t]{2}{*}{ Total acidity (g L-1) } & Lyre & $5.90 \mathrm{~A}^{\mathrm{a}}$ & $5.30 \mathrm{~A}^{\mathrm{b}}$ & $5.55 A^{b}$ & $4.40 \mathrm{~A}^{\mathrm{b}}$ & $4.40 \mathrm{~A}^{\mathrm{b}}$ & $4.63 \mathrm{~A}^{\mathrm{a}}$ \\
\hline & VSP & $6.55 \mathrm{~A}^{\mathrm{a}}$ & $5.45 A^{b}$ & $5.20 A^{b}$ & $4.03 \mathrm{~A}^{\mathrm{b}}$ & $4.10 \mathrm{~A}^{\mathrm{a}}$ & $4.10 \mathrm{~A}^{\mathrm{a}}$ \\
\hline \multirow[t]{2}{*}{ Alcohol (\% v/v) } & Lyre & $10.89 \mathrm{~A}^{\mathrm{b}}$ & $11.02 \mathrm{~A}^{\mathrm{a}}$ & $10.79 \mathrm{~B}^{\mathrm{c}}$ & $12.29 \mathrm{~A}^{\mathrm{a}}$ & $12.24 \mathrm{~A}^{\mathrm{a}}$ & $12.55 \mathrm{~A}^{\mathrm{a}}$ \\
\hline & VSP & $10.5 \mathrm{~B}^{\mathrm{b}}$ & $11.14 \mathrm{~A}^{\mathrm{a}}$ & $11.01 \mathrm{~A}^{\mathrm{a}}$ & $13.40 \mathrm{~A}^{\mathrm{a}}$ & $12.11 \mathrm{~A}^{\mathrm{b}}$ & $13.29 \mathrm{~A}^{\mathrm{a}}$ \\
\hline \multirow[t]{2}{*}{ Dry extract $\left(\mathrm{g} \mathrm{L}^{-1}\right)$} & Lyre & $26.90 \mathrm{~A}^{\mathrm{c}}$ & $28.60 \mathrm{~B}^{\mathrm{b}}$ & $29.50 \mathrm{~A}^{\mathrm{a}}$ & $27.60 \mathrm{~A}^{\mathrm{b}}$ & $30.29 \mathrm{~A}^{\mathrm{a}}$ & $26.83 A^{b}$ \\
\hline & VSP & $27.30 \mathrm{~A}^{\mathrm{c}}$ & $30.75 \mathrm{~A}^{\mathrm{a}}$ & $29.65 A^{b}$ & $28.36 \mathrm{~A}^{\mathrm{a}}$ & $24.70 \mathrm{~B}^{\mathrm{b}}$ & $29.30 \mathrm{~A}^{\mathrm{a}}$ \\
\hline \multirow[t]{2}{*}{ Free $\mathrm{SO}_{2}\left(\mathrm{mg} \mathrm{L}^{-1}\right)$} & Lyre & $30.55 \mathrm{~A}^{\mathrm{a}}$ & $30.72 \mathrm{~A}^{\mathrm{a}}$ & $30.38 \mathrm{~A}^{\mathrm{a}}$ & $45.91 \mathrm{~A}^{\mathrm{b}}$ & $49.66 \mathrm{~A}^{\mathrm{a}}$ & $42.32 \mathrm{~A}^{\mathrm{b}}$ \\
\hline & VSP & $26.28 \mathrm{~B}^{\mathrm{b}}$ & $30.21 \mathrm{~A}^{\mathrm{a}}$ & $25.77 \mathrm{~B}^{\mathrm{b}}$ & $39.70 \mathrm{~B}^{\mathrm{c}}$ & $50.00 A^{a}$ & $46.50 A^{b}$ \\
\hline \multirow[t]{2}{*}{ Total $\mathrm{SO}_{2}\left(\mathrm{mg} \mathrm{L}^{-1}\right)$} & Lyre & $108.88 A^{c}$ & $154.62 \mathrm{~A}^{\mathrm{a}}$ & $13.00 \mathrm{~B}^{\mathrm{b}}$ & $68.4 \mathrm{~B}^{\mathrm{b}}$ & $77.6 \mathrm{~A}^{\mathrm{a}}$ & $70.3 \mathrm{~B}^{\mathrm{b}}$ \\
\hline & VSP & $91.39 \mathrm{~B}^{\mathrm{C}}$ & $106.49 \mathrm{~B}^{\mathrm{b}}$ & $153.77 \mathrm{~A}^{\mathrm{a}}$ & $78.0 A^{a}$ & $73.5 A^{b}$ & $75.4 A^{a}$ \\
\hline \multirow[t]{2}{*}{ Volatile acidity ( $\mathrm{g} \mathrm{L}^{-1}$ ) } & Lyre & $0.62 \mathrm{~A}^{\mathrm{a}}$ & $0.59 \mathrm{~A}^{\mathrm{a}}$ & $0.62 \mathrm{~A}^{\mathrm{a}}$ & $0.98 A^{a}$ & $0.99 \mathrm{~A}^{\mathrm{a}}$ & $0.55 A^{b}$ \\
\hline & VSP & $0.63 \mathrm{~A}^{\mathrm{a}}$ & $0.62 \mathrm{~A}^{\mathrm{a}}$ & $0.48 \mathrm{~B}^{\mathrm{b}}$ & $0.41 \mathrm{~B}^{\mathrm{b}}$ & $0.72 \mathrm{~A}^{\mathrm{a}}$ & $0.39 \mathrm{~B}^{\mathrm{b}}$ \\
\hline \multirow[t]{2}{*}{ Reduced sugars (g L-1) } & Lyre & $3.33 \mathrm{~A}^{\mathrm{a}}$ & $2.27 A^{c}$ & $2.64 \mathrm{~B}^{\mathrm{b}}$ & ND & $1.33 \mathrm{~A}^{\mathrm{a}}$ & $1.39 \mathrm{~A}^{\mathrm{a}}$ \\
\hline & VSP & $3.35 \mathrm{~A}^{\mathrm{a}}$ & ND & $2.79 A^{b}$ & ND & ND & $1.66 \mathrm{~A}^{\mathrm{a}}$ \\
\hline \multirow[t]{2}{*}{ Total phenolics (mg GAE L-1) } & Lyre & $1,900 A^{b}$ & $2,290 \mathrm{~A}^{\mathrm{a}}$ & $1,880 A^{b}$ & $2,270 A^{b}$ & $2,500 A^{a}$ & $2,040 A^{b}$ \\
\hline & VSP & $1,780 \mathrm{~A}^{\mathrm{a}}$ & $1,520 A^{b}$ & $1,500 \mathrm{~B}^{\mathrm{b}}$ & $2,180 A^{a}$ & $1,680 \mathrm{~B}^{\mathrm{b}}$ & $2,400 \mathrm{~A}^{\mathrm{a}}$ \\
\hline \multirow{2}{*}{$\begin{array}{l}\text { Monomeric anthocyanins } \\
\left(\mathrm{mg} \mathrm{MGE} \mathrm{L}^{-1}\right)\end{array}$} & Lyre & $169.07 A^{b}$ & $183.06 \mathrm{~A}^{\mathrm{a}}$ & $178.67 A^{b}$ & $166.99 A^{b}$ & $191.20 \mathrm{~A}^{\mathrm{a}}$ & $185.77 A^{b}$ \\
\hline & VSP & $143.40 \mathrm{~B}^{\mathrm{b}}$ & $253.61 \mathrm{~A}^{\mathrm{a}}$ & $203.10 A^{c}$ & $162.41 \mathrm{~A}^{\mathrm{a}}$ & $177.84 \mathrm{~A}^{\mathrm{a}}$ & $162.41 \mathrm{~A}^{\mathrm{a}}$ \\
\hline \multirow[t]{2}{*}{ IC (420nm+520nm+620nm) } & Lyre & $6.91 A^{b}$ & $6.24 \mathrm{~B}^{\mathrm{C}}$ & $7.64 \mathrm{~A}^{\mathrm{a}}$ & $4.33 \mathrm{~B}^{\mathrm{C}}$ & $5.09 \mathrm{~B}^{\mathrm{b}}$ & $9.17 \mathrm{~A}^{\mathrm{a}}$ \\
\hline & VSP & $7.04 A^{c}$ & $9.75 \mathrm{~A}^{\mathrm{a}}$ & $8.03 A^{b}$ & $6.58 A^{c}$ & $9.47 \mathrm{~A}^{\mathrm{a}}$ & $8.83 \mathrm{~B}^{\mathrm{b}}$ \\
\hline \multirow[t]{2}{*}{$\mathrm{DPPH}\left(\mu \mathrm{mol} \mathrm{TE} \mathrm{mL}^{-1}\right)$} & Lyre & $9.23 \mathrm{~A}^{\mathrm{a}}$ & $8.25 \mathrm{~B}^{\mathrm{b}}$ & $9.24 \mathrm{~A}^{\mathrm{a}}$ & $8.33 \mathrm{~A}^{\mathrm{a}}$ & $7.60 \mathrm{~B}^{\mathrm{C}}$ & $7.97 \mathrm{~A}^{\mathrm{b}}$ \\
\hline & VSP & $8.95 \mathrm{~A}^{\mathrm{a}}$ & $9.23 \mathrm{~A}^{\mathrm{a}}$ & $9.42 \mathrm{~A}^{\mathrm{a}}$ & $7.97 \mathrm{~A}^{\mathrm{b}}$ & $9.54 \mathrm{~A}^{\mathrm{a}}$ & $9.26 \mathrm{~A}^{\mathrm{a}}$ \\
\hline
\end{tabular}

${ }^{1}$ Results followed by the same uppercase letter in the column (training system) do not differ significantly, according to Tukey's Test ( $p \leq 0.05$ ). ${ }^{2}$ Results followed by the same lowercase letter in the row (rootstock) do not differ significantly, according to Tukey's test ( $p \leq 0.05)$. ND: Not detected; GAE: gallic acid equivalent; MGE: malvidin-3-O-glucoside equivalent; TE: trolox equivalent; Lyre: divided trellis system; VSP: vertical shoot positioning, sparlier system. IC: Intensity of color.

$\mathrm{L}^{-1}$ to $30.75 \mathrm{~g} \mathrm{~L}^{-1}$ (Table 1 ). The values for dry extract are lower than those reported by Oliveira et al. (2011) in studies with commercial red wines ( $V$. vinifera $\mathrm{L}$ ) from the São Francisco Valley, ranging from 32.90 to $38.37 \mathrm{~g} \mathrm{~L}^{-1}$. The present values are above the minimum dry extract limit established by the Brazilian legislation, which is $13.0 \mathrm{~g} \mathrm{~L}^{-1}$ (Brazil, 2010). The training system influenced the wines' dry extract content when the grapes were grafted under the IAC 766 rootstock. According to Miele and Rizzon (2019), the main components of the dry extract are organic acids and glycerol, being this an important parameter to regulate the wine body.

In addition, the total $\mathrm{SO}_{2}$ content of the wines ranged from 70.30 to $154.62 \mathrm{mg} \mathrm{L}^{-1}$ (Table 1), below the maximum limit allowed by the Brazilian legislation, which is $350 \mathrm{mg} \mathrm{L}^{-1}$ (Brazil, 2010). The values for volatile acidity varied between 0.39 and $0.99 \mathrm{~g} \mathrm{~L}^{-1}$, which is equivalent to $6.50 \mathrm{mEq} \mathrm{L}^{-1}$ and $16.50 \mathrm{mEq}$ $\mathrm{L}^{-1}$, respectively, and are also within Brazilian legislation stand- ards, which recommends volatile acidity up to $20 \mathrm{mEq} \mathrm{L}^{-1}$ (Brazil, 2010). The importance of maintaining wines with lower contents of volatile acidity relies on the fact that this parameter may negatively influence wine nutritional quality and sensory characteristics. Miele and Rizzon (2019) observed no statistical differences in volatile acidity (ranging from $12-14 \mathrm{meq} \mathrm{L}^{-1}$ ) for Cabernet Sauvignon wines grafted under different rootstocks. In the present study, rootstocks IAC-572 (harvest I and II) and Paulsen 1103 (harvest II) rendered a decreased volatile acidity.

\subsection{Phenolic composition and antioxidant activity}

The total phenolic content (TPC) of wines produced from grapes with different training systems and rootstocks ranged from 1,500 to $2,290 \mathrm{mg}$ gallic acid equivalent (GAE) $\mathrm{L}^{-1}$ for wines from the harvest I and from 1,680 to $2,500 \mathrm{mg} \mathrm{GAE} \mathrm{L}^{-1}$ for the second 
harvest of the 2014 year, being higher for this period, when grapes were harvested at a more advanced maturation stage (Table 1). Biasoto et al. (2014) reported that TPC in red wines usually vary from 1,900 to $3,800 \mathrm{mg} \mathrm{GAE} \mathrm{L}{ }^{-1}$. In the present study, most of the evaluated wines presented phenolic content within the range suggested by these authors. The combination of lyre training system with rootstock IAC 766 yielded the highest concentrations of TPC both for harvest I $\left(2,290 \mathrm{mg} \mathrm{L}^{-1}\right)$ and II $\left(2500 \mathrm{mg} \mathrm{L}^{-1}\right)$. These differences indicate that grape growing practices have a significant influence on wine phenolic composition, as suggested by Gutiérrez-Gamboa et al. (2019). Other factors that can affect this parameter include climatic and processing conditions.

The content of total monomeric anthocyanins (TMA) in wines ranged from 143.40 to $253.61 \mathrm{mg} \mathrm{MGE} \mathrm{L}^{-1}$ for the harvest I and from 162.41 to $191.20 \mathrm{mg} \mathrm{MGE} \mathrm{L}^{-1}$ for those from the harvest II. The concentrations of total monomeric anthocyanins obtained in red wines are in accordance with the results obtained by Padilha et al. (2016), who analyzed commercial red wines of São Francisco Valley and found TMAs between 36.2 and $351.3 \mathrm{mg} \mathrm{L}^{-1}$. In general, wines from grapes grown under the IAC 766 rootstock presented greater TMA, regardless of the harvest and the evaluated training system (Table 1). Similarly, other authors have shown the influence of the rootstock on grape and wine anthocyanins content (Walker et al., 2000; Satisha et al., 2010; Chou and Li 2014; Li et al., 2019; Gutiérrez-Gomboa et al., 2019).

The higher ability of phenolic compounds in scavenging DPPH may be linked to higher biological activities as recently demonstrated in cell model systems (Falcão et al., 2019). The antioxidant activity values evaluated by the DPPH method ranged from 7.60 to $9.54 \mu \mathrm{mol}$ Trolox equivalent (TE) $\mathrm{mL}^{-1}$ (Table 1 ). The antioxidant activity of the wines did not vary according to the harvest season. The training system influenced the antioxidant activity of the wine, only when VSP training system was used in combination with IAC-766 rootstock, yielding slightly lower values. In general, the majority of the wines displayed satisfactory scavenging activity towards the DPPH radical, which is consistent with the presence of phenolic antioxidants in abundance.

\subsection{Identification and quantification of phenolic compounds}

With the use of HPLC-DAD-FD analysis, it was possible to identify and quantify 24 phenolic compounds in the wines (Table 2). Among them, phenolics from different classes, namely flavan3 -ols $(n=7)$, flavonols $(n=6)$, stilbenes $(n=1)$, phenolic acids $(n=5)$, and anthocyanins $(n=5)$ were positively identified. The wines produced with the grapes cultivated in the VSP system and IAC 766 rootstock obtained the highest total flavan-3-ol content in both harvests $\left(I=73.26 \mathrm{mg} \mathrm{L}^{-1}, \mathrm{II}=37.50 \mathrm{mg} \mathrm{L}^{-1}\right)$.

Generally, the wines showed significant amounts of $(+)$ catechin (5.30 to $27.00 \mathrm{mg} \mathrm{L}^{-1}$ ), procyanidin B1 (5.50-14.96 $\mathrm{mg} \mathrm{L}^{-1}$ ), and procyanidin B2 (3.83-14.00 $\left.\mathrm{mg} \mathrm{L}^{-1}\right)$. Padilha et al. (2016) found $(+)$-catechin to be the major component of red wine, with amounts ranging from 2.20 to $40.40 \mathrm{mg} \mathrm{L}^{-1}$. The presence of oligomeric flavan-3-ols (e.g., proanthocyanidins) leads to perceived astringency, rich body, and improved aging properties (Waterhouse et al., 2002). The phenolic-driven sensory changes in several feedstocks has been recently discussed by de Camargo and Schwember (2019).

The Pearson's correlation analysis $(p \leq 0.05)$ aimed to verify the correlation between the antioxidant activity and the quantified phenolic compounds. A positive and significant correlation existed between the antioxidant activity and the total content of flavan3 -ols $(\mathrm{r}=0.56 ; \mathrm{p}=0.05)$, as well as procyanidins A2 $(\mathrm{r}=0.74, \mathrm{p}=$
$0.01)$ and $\mathrm{B} 2(\mathrm{r}=0.57, \mathrm{p}=0.05)$. The wine containing the highest levels of procyanidin A2, B2, and total flavan-3-ols was obtained from grapes grown in a espalier system and grafted on IAC 766 rootstock.

A higher concentration of flavonols was observed for the wines produced in December, when high temperatures are recorded in Brazil. Similar findings were obtained by Pereira et al. (2006) that investigated the climate influence on Merlot wine metabolic profiles with or without the exposition to higher solar radiation. In the present study, an increased amount of flavonols was observed in grapes and wines (harvest II) due to higher solar exposition and temperature.

Flavonols are also considered fundamental for the intensity and stability of red wine color, and also play an important role for their astringency and bitterness (Niculcea et al., 2015). Regardless of the training system, IAC 766 rootstock resulted in higher flavonol contents in grapes from harvest I. On the other hand, IAC 572 rootstock originated wines with higher contents of flavonols in the harvest II. Thus, the choice of rootstock possibly influenced the synthesis of flavonols in grapes as a function of the period of the year. Isoquercetin and isorhanmetin-3-O-glucoside were the main flavonols present in the tested samples, ranging from 9.35 to 41.25 $\mathrm{mgL}^{-1}$ for isoquercetin, and 8.06 to $26.45 \mathrm{mg} \mathrm{L}^{-1}$ for isorhanmetine-3-O-glucoside. The wine produced with grapes obtained from harvest II and grown under lyre system and IAC 572 rootstock showed to be particularly rich in these two compounds. Evaluating grape juices produced in the São Francisco Valley, Nassur et al. (2014) observed that IAC 572 rootstock resulted in significantly high phenolic compounds and anthocyanins levels.

The levels of trans-resveratrol in the wines ranged from 0.20 to $0.50 \mathrm{mg} \mathrm{L}^{-1}$, exhibiting the lowest contribution amongst the phenolic compounds. However, trans-resveratrol content was not influenced by the training system and rootstocks. In contrast, the grapes from harvest II resulted in wines containing higher contents of trans-resveratrol. Similar results were observed by Lucena et al. (2010) for wines from the São Francisco Valley, with contents between 0.04 and $1.26 \mathrm{mg} \mathrm{L}^{-1}$. However, the authors reported that resveratrol in the cis form is found in higher levels than the trans form in wines from this location. Consumption of resveratrol is associated with the prevention of a wide range of chronicdegenerative diseases (Gresele et al., 2011). According to Urvieta et al. (2018), fruits that receive higher UV-B incidence may result in wines with higher resveratrol content, which lends support to the differences observed in the present study. In fact, the wines produced from grapes from harvest I, that received a lower UV-B incidence, also had lower levels of trans-resveratrol, while the opposite was found for the wines produced from the second harvest, which may be explained by the higher UV-B incidence.

The training system and rootstock also influenced the content of phenolic acids of the wines (Table 2). Similar to flavonoids, phenolic acids are of great importance due to their antioxidant activity and can influence the wine quality as well as its stability (Rodtjer et al., 2006). The climatic variability between harvests during the crop year did not play a strong influence on the content of phenolic acids. Gallic (10.50-22.30 $\left.\mathrm{mg} \mathrm{L}^{-1}\right)$ and caffeic (7.00-20.76 mg $\mathrm{L}^{-1}$ ) acids were found to be the primary ones in the wine. Regardless of the harvest, the wine obtained from the grapes grown under a VSP system and grafted on IAC 766 rootstock presented higher total phenolic acids, gallic, and caffeic acids contents. The concentrations of gallic acid in the wines evaluated are similar to those found by Padilha et al. (2016) that studied commercial wines from the São Francisco Valley region. Caraguso and Nardini (2015) evaluated commercial red wines from Italy. The contents of caffeic, syringic, and ferulic acids found in the present study are also 
Table 2. Phenolic compounds identified and quantified in Syrah wines from grapes with different rootstock and training systems

\begin{tabular}{|c|c|c|c|c|c|c|c|}
\hline \multirow{3}{*}{ Phenolic compounds (mg L'-1) } & \multirow{3}{*}{ Training system ${ }^{1}$} & \multicolumn{6}{|c|}{ Rootstock $^{2}$} \\
\hline & & Paulsen 1103 & IAC-766 & IAC-572 & Paulsen 1103 & IAC-766 & IAC-572 \\
\hline & & \multicolumn{3}{|c|}{ June, 2014 (Harvest I) } & \multicolumn{3}{|c|}{ December, 2014 (Harvest II) } \\
\hline \multirow[t]{2}{*}{ (+)-Catechin } & VSP & $16.30 \mathrm{~A}^{\mathrm{c}}$ & $27.00 \mathrm{~A}^{\mathrm{a}}$ & $22.70 \mathrm{~A}^{\mathrm{b}}$ & $7.30 \mathrm{~A}^{\mathrm{b}}$ & $9.40 \mathrm{~A}^{\mathrm{a}}$ & $6.25 \mathrm{~B}^{\mathrm{c}}$ \\
\hline & Lyre & $13.86 \mathrm{~A}^{\mathrm{b}}$ & $16.73 \mathrm{~A}^{\mathrm{b}}$ & $17.40 \mathrm{~A}^{\mathrm{a}}$ & $6.90 \mathrm{~A}^{\mathrm{b}}$ & $5.30 \mathrm{~B}^{\mathrm{c}}$ & $8.20 \mathrm{~A}^{\mathrm{a}}$ \\
\hline \multirow[t]{2}{*}{ (-)-Epicatechin } & VSP & $7.50 \mathrm{~A}^{\mathrm{b}}$ & $10.33 \mathrm{~A}^{\mathrm{a}}$ & $7.00 A^{c}$ & $3.40 \mathrm{~A}^{\mathrm{b}}$ & $4.85 \mathrm{~A}^{\mathrm{b}}$ & $6.25 \mathrm{~A}^{\mathrm{a}}$ \\
\hline & Lyre & $6.00 \mathrm{~B}^{\mathrm{c}}$ & $6.16 \mathrm{~A}^{\mathrm{b}}$ & $6.90 \mathrm{~A}^{\mathrm{a}}$ & $3.23 \mathrm{~B}^{\mathrm{b}}$ & $5.30 \mathrm{~B}^{\mathrm{c}}$ & $8.20 \mathrm{~A}^{\mathrm{a}}$ \\
\hline \multirow[t]{2}{*}{ (-)-Epicatechin Gallate } & VSP & $1.40 \mathrm{~A}^{\mathrm{b}}$ & $2.30 \mathrm{~A}^{\mathrm{a}}$ & $1.43 \mathrm{~A}^{\mathrm{b}}$ & $0.90 \mathrm{~A}^{\mathrm{c}}$ & $1.30 \mathrm{~A}^{\mathrm{a}}$ & $1.10 \mathrm{~A}^{\mathrm{b}}$ \\
\hline & Lyre & $1.40 \mathrm{~A}^{\mathrm{a}}$ & $1.36 \mathrm{~A}^{\mathrm{b}}$ & $1.43 \mathrm{~A}^{\mathrm{a}}$ & $1.16 \mathrm{~A}^{\mathrm{a}}$ & $1.23 \mathrm{~A}^{\mathrm{a}}$ & $1.10 \mathrm{~A}^{\mathrm{a}}$ \\
\hline \multirow[t]{2}{*}{ (-)-Epigallocatechin } & VSP & $3.83 \mathrm{~A}^{\mathrm{a}}$ & $3.36 \mathrm{~A}^{\mathrm{a}}$ & $2.83 \mathrm{~A}^{\mathrm{b}}$ & $2.35 \mathrm{~A}^{\mathrm{b}}$ & $4.80 \mathrm{~A}^{\mathrm{a}}$ & $2.35 A^{b}$ \\
\hline & Lyre & $3.30 \mathrm{~A}^{\mathrm{a}}$ & $2.60 \mathrm{~B}^{\mathrm{c}}$ & $2.83 \mathrm{~A}^{\mathrm{b}}$ & $2.73 \mathrm{~A}^{\mathrm{a}}$ & $2.53 \mathrm{~B}^{\mathrm{b}}$ & $2.45 \mathrm{~A}^{\mathrm{b}}$ \\
\hline \multirow[t]{2}{*}{ Procyanidin A2 } & VSP & $1.10 \mathrm{~A}^{\mathrm{b}}$ & $1.40 \mathrm{~A}^{\mathrm{a}}$ & $1.00 \mathrm{~B}^{\mathrm{c}}$ & $0.60 A^{b}$ & $0.90 \mathrm{~A}^{\mathrm{a}}$ & $0.80 \mathrm{~A}^{\mathrm{a}}$ \\
\hline & Lyre & $1.00 \mathrm{~B}^{\mathrm{b}}$ & $0.90 \mathrm{~B}^{\mathrm{c}}$ & $1.10 \mathrm{~A}^{\mathrm{a}}$ & $0.60 \mathrm{~A}^{\mathrm{a}}$ & $0.50 \mathrm{~B}^{\mathrm{b}}$ & $0.60 \mathrm{~A}^{\mathrm{a}}$ \\
\hline \multirow[t]{2}{*}{ Procyanidin B1 } & VSP & $13.50 \mathrm{~A}^{\mathrm{b}}$ & $14.96 \mathrm{~A}^{\mathrm{a}}$ & $11.13 \mathrm{~A}^{\mathrm{c}}$ & $7.52 \mathrm{~A}^{\mathrm{a}}$ & $6.00 \mathrm{~A}^{\mathrm{c}}$ & $7.15 \mathrm{~B}^{\mathrm{b}}$ \\
\hline & Lyre & $13.93 \mathrm{~A}^{\mathrm{a}}$ & $9.13 \mathrm{BC}^{\mathrm{c}}$ & $10.63 \mathrm{~B}^{b}$ & $7.10 B^{b}$ & $5.50 \mathrm{~B}^{\mathrm{c}}$ & $7.30 \mathrm{~A}^{\mathrm{a}}$ \\
\hline \multirow[t]{2}{*}{ Procyanidin B2 } & VSP & $8.53 \mathrm{~A}^{\mathrm{c}}$ & $14.00 \mathrm{~A}^{\mathrm{a}}$ & $10.03 A^{b}$ & $5.55 \mathrm{~A}^{\mathrm{b}}$ & $10.25 \mathrm{~A}^{\mathrm{a}}$ & $7.15 \mathrm{~B}^{\mathrm{b}}$ \\
\hline & Lyre & $6.50 \mathrm{~B}^{\mathrm{c}}$ & $9.80 \mathrm{~A}^{\mathrm{a}}$ & $9.03 \mathrm{~B}^{\mathrm{b}}$ & $5.06 \mathrm{~A}^{\mathrm{b}}$ & $3.83 \mathrm{~B}^{\mathrm{c}}$ & $7.30 \mathrm{~A}^{\mathrm{a}}$ \\
\hline \multirow[t]{2}{*}{$\Sigma$ Flavan-3-ols } & VSP & $52.16 A^{c}$ & $73.26 A^{a}$ & $56.13 A^{b}$ & $27.62 A^{b}$ & $37.50 \mathrm{~A}^{\mathrm{a}}$ & $24.20 \mathrm{~B}^{\mathrm{C}}$ \\
\hline & Lyre & $46.00 \mathrm{~B}^{\mathrm{c}}$ & $46.70 \mathrm{~B}^{\mathrm{b}}$ & $49.33 A^{a}$ & $26.78 A^{b}$ & $24.19 A^{b}$ & $35.15 \mathrm{~A}^{\mathrm{a}}$ \\
\hline \multirow[t]{2}{*}{ Kaempferol-3-O-glucoside } & VSP & $0.66 A^{b}$ & $1.20 \mathrm{~A}^{\mathrm{a}}$ & $0.56 \mathrm{~A}^{\mathrm{b}}$ & $5.70 \mathrm{~B}^{\mathrm{b}}$ & $6.35 \mathrm{~A}^{\mathrm{a}}$ & $6.10 A^{b}$ \\
\hline & Lyre & $0.66 \mathrm{~A}^{\mathrm{a}}$ & $0.46 \mathrm{~A}^{\mathrm{b}}$ & $0.43 A^{b}$ & $6.36 A^{b}$ & $5.70 \mathrm{~B}^{\mathrm{c}}$ & $7.15 \mathrm{~A}^{\mathrm{a}}$ \\
\hline \multirow[t]{2}{*}{ Isorhamnetin-3-O-glucoside } & VSP & $9.06 \mathrm{~A}^{\mathrm{b}}$ & $13.53 \mathrm{~A}^{\mathrm{a}}$ & $8.66 A^{c}$ & $11.95 \mathrm{~B}^{\mathrm{b}}$ & $11.70 \mathrm{~B}^{\mathrm{c}}$ & $17.35 \mathrm{~A}^{\mathrm{a}}$ \\
\hline & Lyre & $8.06 \mathrm{~B}^{\mathrm{b}}$ & $8.10 \mathrm{~B}^{\mathrm{b}}$ & $8.53 \mathrm{~A}^{\mathrm{a}}$ & $22.83 \mathrm{~A}^{\mathrm{b}}$ & $19.50 \mathrm{~A}^{\mathrm{b}}$ & $26.45 \mathrm{~A}^{\mathrm{a}}$ \\
\hline \multirow[t]{2}{*}{ Rutin } & VSP & $0.90 A^{c}$ & $1.30 \mathrm{~A}^{\mathrm{a}}$ & $1.00 \mathrm{~A}^{\mathrm{b}}$ & $0.45 \mathrm{~B}^{\mathrm{b}}$ & $0.50 \mathrm{~B}^{\mathrm{b}}$ & $1.30 \mathrm{~A}^{\mathrm{a}}$ \\
\hline & Lyre & $0.90 \mathrm{~A}^{\mathrm{a}}$ & $0.90 \mathrm{~A}^{\mathrm{a}}$ & $0.83 \mathrm{~A}^{\mathrm{b}}$ & $1.40 \mathrm{~A}^{\mathrm{b}}$ & $1.40 \mathrm{~A}^{\mathrm{b}}$ & $1.75 \mathrm{~A}^{\mathrm{a}}$ \\
\hline \multirow[t]{2}{*}{ Quercetin } & VSP & $0.20 \mathrm{NS}$ & $0.20 \mathrm{NS}$ & $0.20 \mathrm{NS}$ & $0.30 \mathrm{~B}^{\mathrm{c}}$ & $0.70 \mathrm{~A}^{\mathrm{a}}$ & $0.40 \mathrm{~B}^{\mathrm{b}}$ \\
\hline & Lyre & $0.20 \mathrm{NS}$ & $0.20 \mathrm{NS}$ & $0.20 \mathrm{NS}$ & $0.60 A^{b}$ & $0.60 \mathrm{~B}^{\mathrm{b}}$ & $0.90 \mathrm{~A}^{\mathrm{a}}$ \\
\hline \multirow[t]{2}{*}{ Myricetin } & VSP & $0.86 A^{b}$ & $1.33 \mathrm{~A}^{\mathrm{a}}$ & $0.96 A^{b}$ & $0.60 \mathrm{~A}^{\mathrm{b}}$ & $1.15 \mathrm{~A}^{\mathrm{a}}$ & $0.60 \mathrm{~B}^{\mathrm{b}}$ \\
\hline & Lyre & $0.76 A^{c}$ & $1.10 \mathrm{~A}^{\mathrm{b}}$ & $1.00 \mathrm{~A}^{\mathrm{a}}$ & $1.00 \mathrm{~A}^{\mathrm{a}}$ & $0.70 \mathrm{~B}^{\mathrm{b}}$ & $1.25 \mathrm{~A}^{\mathrm{a}}$ \\
\hline \multirow[t]{2}{*}{ Isoquercetin } & VSP & $13.50 \mathrm{~A}^{\mathrm{c}}$ & $18.33 \mathrm{~A}^{\mathrm{a}}$ & $14.0 A^{b}$ & $15.90 \mathrm{~B}^{\mathrm{b}}$ & $9.35 B^{c}$ & $29.45 \mathrm{~A}^{\mathrm{a}}$ \\
\hline & Lyre & $12.90 \mathrm{~A}^{\mathrm{a}}$ & $12.80 \mathrm{~A}^{\mathrm{b}}$ & $12.26 \mathrm{~A}^{\mathrm{b}}$ & $30.75 A^{b}$ & $29.16 A^{b}$ & $41.25 A^{a}$ \\
\hline \multirow[t]{2}{*}{$\Sigma$ Flavonols } & VSP & $25.20 \mathrm{~A}^{\mathrm{b}}$ & $35.90 \mathrm{~A}^{\mathrm{a}}$ & $25.40 \mathrm{~A}^{\mathrm{b}}$ & $34.90 \mathrm{~B}^{b}$ & $29.75 B^{c}$ & $55.20 \mathrm{~A}^{\mathrm{a}}$ \\
\hline & Lyre & $23.50 \mathrm{~A}^{\mathrm{b}}$ & $24.00 \mathrm{~A}^{\mathrm{a}}$ & $23.25 \mathrm{~A}^{\mathrm{b}}$ & $62.96 \mathrm{~A}^{\mathrm{b}}$ & $57.06 A^{c}$ & $78.75 A^{a}$ \\
\hline \multirow[t]{2}{*}{ Trans-resveratrol (Stilbene) } & VSP & $0.20 \mathrm{NS}$ & $0.20 \mathrm{NS}$ & $0.20 \mathrm{NS}$ & $0.50 \mathrm{NS}$ & $0.50 \mathrm{NS}$ & $0.50 \mathrm{NS}$ \\
\hline & Lyre & $0.20 \mathrm{NS}$ & $0.20 \mathrm{NS}$ & $0.20 \mathrm{NS}$ & 0.46 NS & 0.46 NS & $0.50 \mathrm{NS}$ \\
\hline \multirow[t]{2}{*}{ Gallic acid } & VSP & $13.83 A^{c}$ & $20.73 \mathrm{~A}^{\mathrm{a}}$ & $14.56 \mathrm{~A}^{\mathrm{b}}$ & $16.85 \mathrm{~A}^{\mathrm{b}}$ & $22.30 \mathrm{~A}^{\mathrm{a}}$ & $12.20 \mathrm{~B}^{\mathrm{c}}$ \\
\hline & Lyre & $13.16 \mathrm{~A}^{\mathrm{a}}$ & $12.00 \mathrm{~B}^{\mathrm{b}}$ & $13.03 A^{b}$ & $16.16 \mathrm{~A}^{\mathrm{a}}$ & $10.50 \mathrm{~B}^{\mathrm{c}}$ & $15.25 A^{b}$ \\
\hline \multirow[t]{2}{*}{ Caffeic acid } & VSP & $7.00 \mathrm{~B}^{\mathrm{c}}$ & $20.76 A^{a}$ & $8.40 \mathrm{~B}^{\mathrm{b}}$ & $12.20 \mathrm{~A}^{\mathrm{b}}$ & $20.40 \mathrm{~A}^{\mathrm{a}}$ & $10.90 \mathrm{~B}^{\mathrm{c}}$ \\
\hline & Lyre & $15.60 \mathrm{~A}^{\mathrm{a}}$ & $12.46 \mathrm{~B}^{\mathrm{b}}$ & $8.96 A^{c}$ & $10.36 \mathrm{~B}^{\mathrm{b}}$ & $9.80 B^{c}$ & $13.80 \mathrm{~A}^{\mathrm{a}}$ \\
\hline \multirow[t]{2}{*}{ Chlorogenic acid } & VSP & $5.20 \mathrm{~A}^{\mathrm{a}}$ & $0.93 \mathrm{~B}^{\mathrm{c}}$ & $4.30 \mathrm{~B}^{\mathrm{b}}$ & $0.40 \mathrm{NS}$ & $0.40 \mathrm{NS}$ & ND \\
\hline & Lyre & $2.30 \mathrm{~B}^{\mathrm{c}}$ & $2.90 A^{b}$ & $5.13 \mathrm{~A}^{\mathrm{a}}$ & 0.40 NS & 0.40 NS & ND \\
\hline
\end{tabular}


Table 2. Phenolic compounds identified and quantified in Syrah wines from grapes with different rootstock and training systems - (continued)

\begin{tabular}{|c|c|c|c|c|c|c|c|}
\hline \multirow{3}{*}{ Phenolic compounds (mg L-1) } & \multirow{3}{*}{ Training system ${ }^{1}$} & \multicolumn{6}{|c|}{ Rootstock $^{2}$} \\
\hline & & Paulsen 1103 & IAC-766 & IAC-572 & Paulsen 1103 & IAC-766 & IAC-572 \\
\hline & & \multicolumn{3}{|c|}{ June, 2014 (Harvest I) } & \multicolumn{3}{|c|}{ December, 2014 (Harvest II) } \\
\hline \multirow[t]{2}{*}{ Syringic acid } & VSP & $3.63 A^{b}$ & $4.56 \mathrm{~A}^{\mathrm{a}}$ & $2.90 \mathrm{~A}^{\mathrm{c}}$ & $1.30 \mathrm{~A}^{\mathrm{b}}$ & $1.50 \mathrm{~A}^{\mathrm{a}}$ & $1.10 \mathrm{~B}^{\mathrm{c}}$ \\
\hline & Lyre & $3.23 \mathrm{~A}^{\mathrm{b}}$ & $3.06 \mathrm{~B}^{\mathrm{b}}$ & $4.20 \mathrm{~A}^{\mathrm{a}}$ & $1.20 \mathrm{~B}^{\mathrm{b}}$ & $0.93 \mathrm{~B}^{\mathrm{c}}$ & $1.50 \mathrm{~A}^{\mathrm{a}}$ \\
\hline \multirow[t]{2}{*}{ Ferulic acid } & VSP & $0.30 A^{b}$ & $0.56 \mathrm{~A}^{\mathrm{a}}$ & $0.33 A^{b}$ & $0.95 \mathrm{~A}^{\mathrm{c}}$ & $1.20 \mathrm{~A}^{\mathrm{a}}$ & $1.05 \mathrm{~A}^{\mathrm{b}}$ \\
\hline & Lyre & $0.43 \mathrm{~A}^{\mathrm{a}}$ & $0.36 \mathrm{~A}^{\mathrm{a}}$ & $0.36 \mathrm{~A}^{\mathrm{a}}$ & $0.96 \mathrm{~A}^{\mathrm{b}}$ & $0.80 \mathrm{~B}^{\mathrm{c}}$ & $1.10 \mathrm{~A}^{\mathrm{a}}$ \\
\hline \multirow[t]{2}{*}{$\Sigma$ Phenolic acids } & VSP & $29.96 A^{b}$ & $47.56 \mathrm{~A}^{\mathrm{a}}$ & $30.50 A^{b}$ & $31.70 \mathrm{~A}^{\mathrm{b}}$ & $45.80 \mathrm{~A}^{\mathrm{a}}$ & $25.25 \mathrm{~B}^{\mathrm{C}}$ \\
\hline & Lyre & $34.73 \mathrm{~A}^{\mathrm{a}}$ & $30.80 \mathrm{~B}^{\mathrm{b}}$ & $31.70 \mathrm{~A}^{\mathrm{a}}$ & $29.10 \mathrm{~B}^{\mathrm{b}}$ & $22.43 \mathrm{~B}^{\mathrm{C}}$ & $31.65 \mathrm{~A}^{\mathrm{a}}$ \\
\hline \multirow[t]{2}{*}{ Malvidin 3-O-glucoside } & VSP & $63.30 A^{c}$ & $105.13 \mathrm{~A}^{\mathrm{a}}$ & $86.16 A^{b}$ & $55.05 \mathrm{~B}^{\mathrm{c}}$ & $83.20 \mathrm{~A}^{\mathrm{a}}$ & $63.95 \mathrm{~B}^{\mathrm{b}}$ \\
\hline & Lyre & $53.53 \mathrm{~B}^{\mathrm{c}}$ & $84.50 \mathrm{~A}^{\mathrm{a}}$ & $73.10 A^{b}$ & $60.83 A^{b}$ & $52.90 \mathrm{~B}^{\mathrm{c}}$ & $70.20 A^{a}$ \\
\hline \multirow[t]{2}{*}{ Delphinidin 3-O-glucoside } & VSP & $1.10 \mathrm{~A}^{\mathrm{c}}$ & $1.80 \mathrm{~A}^{\mathrm{a}}$ & $1.50 A^{b}$ & $1.60 A^{b}$ & $1.50 \mathrm{~A}^{\mathrm{c}}$ & $2.95 \mathrm{~A}^{\mathrm{a}}$ \\
\hline & Lyre & $0.90 \mathrm{~B}^{\mathrm{c}}$ & $1.10 \mathrm{~B}^{\mathrm{b}}$ & $1.43 \mathrm{~A}^{\mathrm{a}}$ & $1.80 \mathrm{~B}^{\mathrm{b}}$ & $1.10 \mathrm{~B}^{\mathrm{c}}$ & $2.05 A^{a}$ \\
\hline \multirow[t]{2}{*}{ Peonidin 3-O-glucoside } & VSP & $1.90 \mathrm{~A}^{\mathrm{c}}$ & $2.53 A^{a}$ & $2.03 A^{b}$ & $2.85 \mathrm{~B}^{\mathrm{b}}$ & $1.90 \mathrm{~B}^{\mathrm{c}}$ & $4.05 \mathrm{~A}^{\mathrm{a}}$ \\
\hline & Lyre & $1.63 \mathrm{~B}^{\mathrm{c}}$ & $1.80 \mathrm{~B}^{\mathrm{b}}$ & $1.90 \mathrm{~A}^{\mathrm{a}}$ & $3.20 \mathrm{~A}^{\mathrm{a}}$ & $2.00 \mathrm{~A}^{\mathrm{c}}$ & $3.10 \mathrm{~B}^{\mathrm{b}}$ \\
\hline \multirow[t]{2}{*}{ Pelargonidin 3-O-glucoside } & VSP & $4.86 \mathrm{~A}^{\mathrm{c}}$ & $9.03 A^{a}$ & $7.33 \mathrm{~A}^{\mathrm{b}}$ & $6.40 \mathrm{~B}^{\mathrm{c}}$ & $7.15 A^{b}$ & $9.65 \mathrm{~A}^{\mathrm{a}}$ \\
\hline & Lyre & $4.20 \mathrm{BC}^{\mathrm{C}}$ & $5.93 A^{b}$ & $6.76 \mathrm{~A}^{\mathrm{a}}$ & $6.76 A^{b}$ & $4.93 \mathrm{~B}^{\mathrm{c}}$ & $8.20 \mathrm{~A}^{\mathrm{a}}$ \\
\hline \multirow[t]{2}{*}{ Petunidin 3-O-glucoside } & VSP & $0.50 A^{b}$ & $0.60 A^{a}$ & $0.50 A^{b}$ & $0.60 A^{a}$ & $0.55 A^{a}$ & $0.60 \mathrm{~A}^{\mathrm{a}}$ \\
\hline & Lyre & $0.66 \mathrm{~A}^{\mathrm{a}}$ & $0.50 \mathrm{~B}^{\mathrm{b}}$ & $0.43 A^{b}$ & $0.60 \mathrm{~A}^{\mathrm{a}}$ & $0.50 \mathrm{~B}^{\mathrm{b}}$ & $0.60 \mathrm{~A}^{\mathrm{a}}$ \\
\hline \multirow[t]{2}{*}{$\Sigma$ Anthocyanins } & VSP & $71.66 A^{c}$ & $119.10 \mathrm{~A}^{\mathrm{a}}$ & $47.53 \mathrm{~A}^{\mathrm{b}}$ & $66.45 \mathrm{~B}^{\mathrm{c}}$ & $94.35 \mathrm{~A}^{\mathrm{a}}$ & $81.20 \mathrm{~B}^{\mathrm{b}}$ \\
\hline & Lyre & $60.93 \mathrm{~B}^{\mathrm{c}}$ & $93.83 A^{a}$ & $83.63 \mathrm{~B}^{\mathrm{b}}$ & $73.20 A^{b}$ & $61.43 A^{b}$ & $84.15 A^{a}$ \\
\hline
\end{tabular}

${ }^{1}$ Results followed by the same uppercase letter in the column (training system) do not differ significantly, according to Tukey's Test ( $\left.p \leq 0.05\right)$. ${ }^{2}$ Results followed by the same lowercase letter in the row (rootstock) do not differ significantly, according to Tukey's test ( $\leq \leq 0.05)$. ND: Not detected; NS: not significant; Lyre: divided trellis system; VSP: vertical shoot positioning, sparlier system.

close to those reported by these authors.

Irrespective of the harvesting season and training system, increased anthocyanin levels were found in wines from grapes grafted under the IAC 766 rootstock. Wines from grapes of the harvest I cultivated in a VSP system with the IAC 766 rootstock presented a total anthocyanin content of $119.10 \mathrm{mg} \mathrm{L}^{-1}$, while, under the same training system and rootstock, the wines elaborated from grapes of the harvest II resulted in $94.35 \mathrm{mg} \mathrm{L}^{-1}$ (Table 2). The total anthocyanin content of the evaluated wines is within the range found by Padilha et al. (2016), who analyzed VSF commercial red wines of different Vitis vinifera L. varieties, and found concentrations ranging between 6.5 and $141.7 \mathrm{mg} \mathrm{L}^{-1}$. Through co-pigmentation and formation of polymeric pigments, anthocyanins participate in the main reactions resulting in wine color, being responsible for the red, purple, and blue tones (Lee et al., 2008). Regardless of harvest season it can be observed (Table 1) that the combination of IAC 766 and the VSP system resulted in wines with higher color intensity. Malvidin-3-O-glucoside rendered the highest contribution to the phenolic profile in all wines analyzed. In the samples obtained from the combination of VSP and IAC 766, the values of this anthocyanin for harvests I and II were 105.13 and $83.20 \mathrm{mg}$ $\mathrm{L}^{-1}$, respectively.

Figure 1 shows about the Principal Component Analysis (PCA). The results demonstrate that the climatic variability between the harvesting seasons influenced the profile of phenolic compounds of the wines more than the evaluated rootstock or training sys- tem. The wines from harvest I are located on the positive side of CP1, which explains $48.26 \%$ of the variability among the samples, while the wines from the harvest II were located on the negative side of this component. The wines of the harvest II were highlighted in the anthocyanins pelargonidin-3-O-glucoside, petunidin3-O-glucoside, delfinidin-3-O-glucoside, peonidin-3- $O$-glucoside, trans-resveratrol, ferulic acid, and of most flavonols, except in myricetin. In contrast, the wines from harvest I were closer to the vectors that represent all the other phenolic compounds that were quantified in the samples.

\section{Conclusions}

The influence of training systems and rootstocks on the quality of the Syrah tropical wines from São Francisco Valley, Brazil, was addressed in this study. Both affected the wine quality in different ways. Among the variables (e.g. harvests, training systems, and rootstocks), the PCA analysis showed that the climatic variability between the two harvests of the year had the most prominent influence. In general, the use of espalier training system combined with rootstock IAC-766 rendered wines with increased contents of flavan-3-ols, flavonols, phenolic acids, and anthocyanins. However, in order to recommend an optimum combination of training system and rootstock, further studies under field conditions and the evaluation of a larger number of harvests are required. 


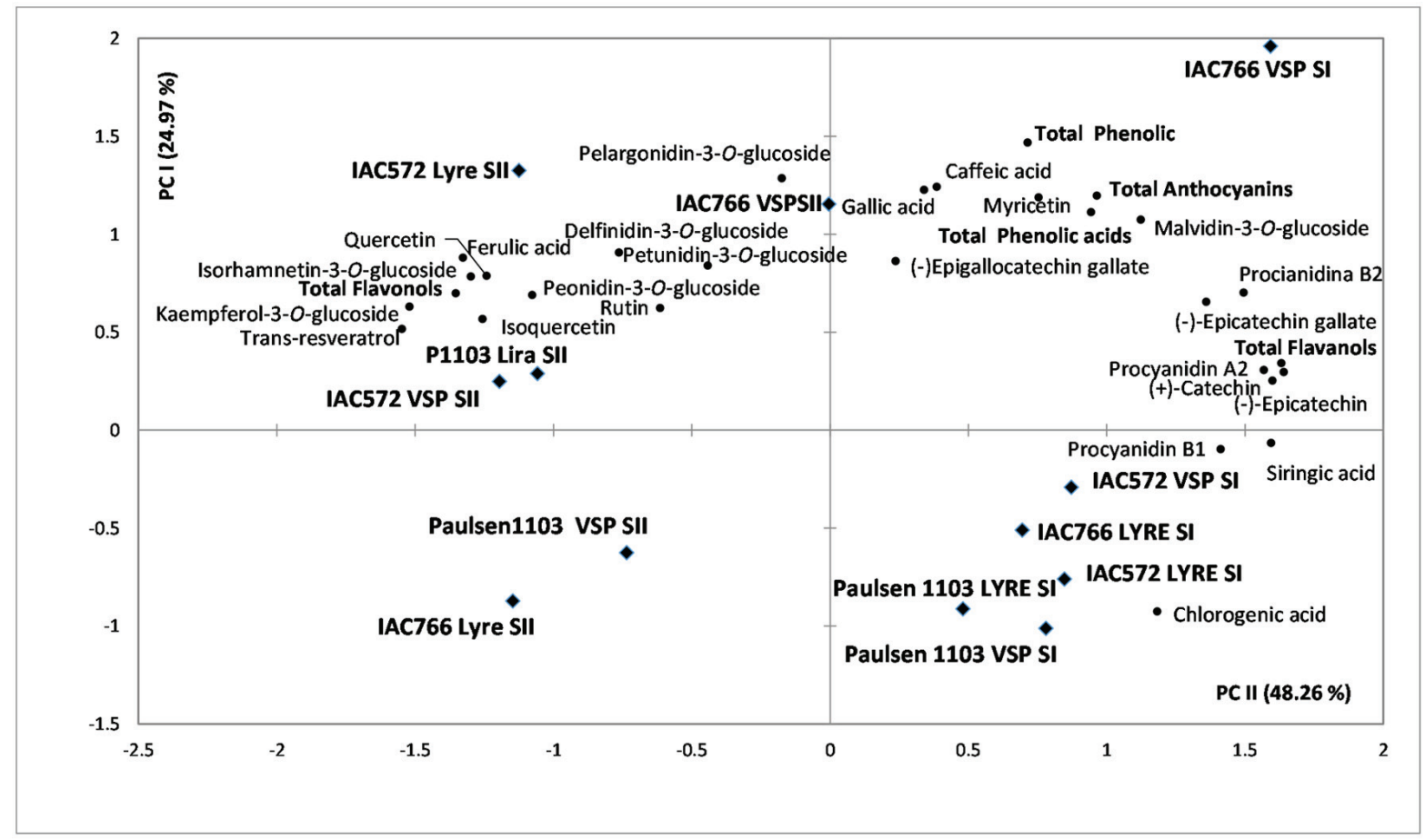

Figure 1. Principal Component Analysis (PCA) of the phenolics quantified $(n=24)$ by HPLC-DAD-FD in Syrah tropical wines from grapes grown under lyre and VSP training systems using the IAC-766, IAC-572, and Paulsen 1103 rootsotcks, harvested during two periods of the year in 2014 (Harvest I and II). $\mathrm{Esp}=\mathrm{VSP}, \mathrm{SI}=$ harvest I, SII = harvest II, P1103 = Paulsen 1103, Ac. = acid.

Acknowledgments

The authors are grateful to the Bahia State Foundation for Research Support-FAPESB (process 7235/2014) for providing a scholarship and to the Brazilian Agricultural Research Corporation for financially supporting this research.

\section{References}

Alañón, M.E., Pérez-Coello, M.S., and Marina, M.L. (2015). Wine science in the metabolomics era. TrAC Trend Anal. Chem. 74: 1-20.

Andrade, M.F., Souza, D.J.P., Silva, J.B.P., and Paim, A.P.S. (2008). Análises multivariada de parâmetros físico-químicos em amostras de vinhos tintos comercializados na região metropolitana do Recife. Quim. Nova 31: 296-300.

Biasoto, A.C.T., Netto, F.M., Marques, E.J.N., and da Silva, M.A.A.P. (2014). Acceptability and preference drivers of red wines produced from $\mathrm{Vi}$ tis labrusca and hybrid grapes. Food Res. Int. 62: 456-466.

Brand-Williams, W., Cuvelier, M.E., and Berset, C. (1995). Use of a free radical method to evaluate antioxidant activity. LWT - Food Sci. Technol. 28: 25-30.

Brazil. Ministério da Agricultura Pecuária e Abastecimento-MAPA. (2010). Portaria no 259 de 31 de maio de 2010. Estabelece a complementação dos padrões de identidade e qualidade do vinho e derivados da uva e do vinho. http://extranet.agricultura.gov.br/sislegis-consulta. Accessed 25 Aug. 2019.

Carbonnea, U.A., Deloire, A., and Jaillard, B. (2007). Viticulture. La vigne: Physiologie, terroir, culture. Dunod, Paris, p. 441

Cassino, C., Tsolakis, C., Bonello, F., Gianotti, V., and Osella, D. (2017). Effects of area, year and climatic factors on Barbera wine characteristics studied by the combination of $1 \mathrm{H}-\mathrm{NMR}$ metabolomics and chemometrics. J. Wine Res. 28: 259-277.

Chou, M-I., and Li, K-T. (2014). Rootstock and seasonal variations affect anthocyanin accumulation and quality traits of 'Kyoho' grape berries in subtropical double cropping system. Vitis 53: 193-199.

Cueva, C., Gil-Sánchez, I., Moreno-Arribas, M.V., and Bartolomé, B. (2016). Interactions between wine polyphenols and gut microbiota. In: Moreno-Arribas, M.V., and Suáldea, B.B. (Ed.). Wine Safety, Consumer Preference, and Human Health. Springer, Cham, pp. 259-278. de Camargo, A.C., Regitano-D’Arce, M.A.B., Biasoto, A.C.T., and Shahidi, F. (2014). Low molecular weight phenolics of grape juice and winemaking byproducts: antioxidant activities and inhibition of oxidation of human low-density lipoprotein cholesterol and DNA strand breakage. J. Agr. Food Chem. 62: 12159-12171.

de Camargo, A.C., and Schwember, A.R. (2019). Phenolic-driven sensory changes in functional foods. J. Food Bioact. 5: 6-7.

de Oliveira, W.P., Biasoto, A.C.T., Marques, V.F., dos Santos, I.M., Magalhães, K., Correa, L.C., and and Shahidi, F. (2017). Phenolics from winemaking by-products better decrease VLDL-cholesterol and triacylglycerol levels than those of red wine in Wistar rats. J. Food Sci. 82: 2432-2437.

Falcão, H.G., Silva, M.B.R., de Camargo, A.C., Shahidi, F., Franchin, M., Rosalen, P.L., Alencar, S.M., Kurozawa, L.E., and Ida, E.I. (2019). Optimizing the potential bioactivity of isoflavones from soybeans via ultrasound pretreatment: Antioxidant potential and NF-KB activation. J. Food Biochem 43: e13018.

Fernandes, I., Perez-Gregorio, R., Soares, S., Mateus, N., and De Freitas, V. (2017). Wine flavonoids in health and disease prevention. Molecules 22: 292.

Forester, S., and Waterhouse, A. (2009). Metabolites are key to understanding health effects of wine Polyphenolics. J. Nutr. 139: 1824S18315 .

Garaguso, I., and Nardini, M. (2015). Polyphenols content, phenolics profile and antioxidant activity of organic red wines produced without sulfur dioxide/sulfites addition in comparison to conventional red wines. Food Chem. 179: 336-342.

Greselea, P., Cerlettiscib, C., Guglielminia, G., Pignatellic, P., Gaetanob, G., and Violic, F. (2011). Effects of resveratrol and other wine polyphe- 
nols on vascular function: an update. J. Nutr. Biochem. 22: 201-211.

Gutiérrez-Gamboa, G., Gómez-Plaza, E., Bautista-Ortín, A.B., GardeCerdán, T., Moreno-Simunovic, Y., and Martínez-Gil, A.M. (2019). Rootstock effects on grape anthocyanins, skin and seed proanthocyanidins and wine color and phenolic compounds from Vitis vinifera L. Merlot grapevines. J. Sci. Food Agr. 99: 2846-2854

Jackson, R.S. (2008). Wine science: Principles, practice and perception (2018 ed). Elsevier, San Diego.

Lee, J., Durst, R.W., and Wrolstad, R.E. (2005). Determination of total monomeric anthocyanin pigment content of fruit juices, beverages, natural colorants, and wines by the $\mathrm{pH}$ differential method: Collaborative Study. J. AOCS Int. 88: 1269-1278.

Lee, J., Rennaker, C., and Wrolstad, R.E. (2008). Correlation of two anthocyanin quantification methods: HPLC and spectrophotometric methods. Food Chem. 110: 782-786.

Li, M., Guo, Z., Jia, N., Yuan, J., Han, B., Yin, Y., Sun, Y., Liu, C., and Zha, S. (2019). Evaluation of eight rootstocks on the growth and berry quality of 'Marselan' grapevines. Sci. Hort. 248: 58-61.

Lima, M.D.S., Leite, A.P.D.S., Sampaio, Y.C., Vianello, F., and Lima, G.P.P. (2015). Influences of the harvest season on analytical characteristics of Syrah Grapes and wines produced in the Northeast Region of Brazil. IJAFP 5: 151-159.

Llaudy, M.C., Canals, R., Canals, J.M., and Zamora, F. (2008). Influence of ripening stage and maceration length on the contribution of grape skins, seeds and stems to phenolic composition and astringency in wine simulated macerations. Eur. Food Res. Technol. 226: 337-344.

Lucena, A.P.S., Nascimento, R.J.B., Maciel, J.A.C., Tavares, J.X., Barbosa-Filho, J.M., and Oliveira, J.E. (2010). Antioxidant activity and phenolics content of selected Brazilian wines. J. Food Compos. Anal. 23: 30-36.

Miele, A.Mandelli, F., and Sistemas de videiras-Embapa Uva e vinho (2014). http://www.cnpuv.embrapa.br/publica/sprod/viticultura/espald. html. Accessed 9 Aug. 2018

Miele, A., and Rizzon, L.A. (2019). Rootstock-scion interaction: 3. Effect on the composition of Cabernet Sauvignon wine. Rev. Bras. Frutic. 41: 1-9.

Moreno, D., Valdés, E., Uriarte, D., Gameroa, E., Talaverano, I., and Vilanova, M. (2017). Early leaf removal applied in warm climatic conditions: impact on Tempranillo wine volatiles. Food Res. Int. 98: 50-58.

Nassur, R.D.C.M.R., Pereira, G.E., Glória, M.B.A., and Lima, L.C.O. (2017). Rootstock influencing the quality and biogenic amines content on Syrah tropical wines. Com. Sci. 8: 202-208.

Nassur, R.D.C.M.R., Pereira, G.E., Alves, J.A., and Lima, L.C.D.O. (2014). Chemical characteristics of grape juices from different cultivar and rootstock combinations. Pesqui. Agropecu. Bras. 49: 540-545.

Natividade, M.M.P., Correa, L.C., Souza, S.V.C., Pereira, G.E., and Lima, L.C.O. (2013). Simultaneous analysis of 25 phenolic compounds in grape juice for HPLC: Method validation and characterization of Sao Francisco Valley samples. Microchem. J. 110: 665-674.

Niculcea, M., Martinez-Lapuente, L., Guadalupe, Z., Sánchez-Díaz, B., Ayestarán, M., and Antolín, M.C. (2015). Characterization of phenolic composition of Vitis vinifera L. 'Tempranillo' and 'Graciano' subjected to deficit irrigation during berry development. Vitis 54: 9-16.

Oliveira, L.C., Souza, S.O., and Mamede, M.E.O. (2011). Avaliação das características físico-químicas e colorimétricas de vinhos finos de duas principais regiões vinícolas do Brasil. Rev. Inst. Adolfo Lutz. 70: 158-67.

Orduña, R.M. (2010). Climate change associated effects on grape and wine quality and production. Food Res. Int. 43: 1844-1855.

Organisation Internationale De La Vigne Et Du Vin Vine and wine outlook. (2015). http://www,oiv,int/oiv/info/es-Bilan_OIV_Mainz_2015. Ac- cessed 10 Aug. 2019.

Ough, C.S., and Amerine, M.A. (1998). Methods for analysis of musts and wine. John Wiley \& Sons. Inc., New York.

Padilha, C.V.S., Biasoto, A.C.T., Corrêa, L.C., Lima, M.S., and Pereira, G.E. (2016). Phenolic compounds and antioxidant activity of commercial tropical 2 red wines (Vitis vinifera $L$ ) from São Francisco valley, Brazil. J. Food Biochem. 2016: 1-9.

Pereira, G.E., Gaudillere, J.P., Pieri, P., Hilbert, G., Maucourt, M., Deborde, C., and Rolin, D. (2006). Microclimate influence on mineral and metabolic profiles of grape berries. J. Agr. Food Chem. 54: 6765-6775.

Pereira, G.E., Padilha, C.V.S., Biasoto, A.C.T., Canuto, K.M., Nascimento, A.M., and Souza, J.F. (2016). Le poids des consommateurs sur évolution des vins: exemple de la Vallée du São Francisco, Brésil. In: Pérard, J., and Perrot, M. (Ed.). Vin et civilisation. Les étapes de I'humanisation. Dijon, Centre Georges Chevrier, pp. 301-310.

Peynaud, E. (1997). Connaissance et travail du vin. Dunod, Paris, p. 341.

Piccardo, D., Favre, G., Pascual, O., Canals, M.J., Zamora, F., and GonzálezNeves, G. (2019). Influence of the use of unripe grapes to reduce ethanol content and $\mathrm{pH}$ on the color, polyphenol and polysaccharide composition of conventional and hot macerated Pinot Noir and Tannat wines. Eur. Food Res. Technol. 245: 1321-1335.

Regina, M.A., Pereira, A.F., Alvarenga, A.A., Antunes, L.E.C., Abrhão, E., and Rodrigues, D.J. (1998). Sistemas de Condução para Videiras. Informe Agropecuário 194: 28-33.

Ribéreau-Gayon, P., Glories, Y., Maujean, A., and Dubourdieu, D. (2006). Handbook of enology: The chemistry of wine, stabilization and treatments ( 2 ed). J. Wiley, Chichester.

Rodtjer, A., Skibsted, L.H., and Andersen, M.L. (2006). Antioxidative and prooxidative effects of extracts made from cherry liqueur pomace. Food Chem. 99: 6-14.

Santos, H.P. Aspectos ecofisiológicos na condução da videira e sua influência na produtividade do vinhedo e na qualidade dos vinhos. Embrapa Uva e Vinho: Bento Gonçalves, RS (2006)-Comunicado Técnico, 71. https://www.embrapa.br/busca-de-publicacoes/-/publicacao/541896/aspectos-ecofisiologicos-na-conducao-da-videirae-sua-influencia-na-produtividade-do-vinhedo-e-na-qualidade-dosvinhos. Accessed 10 Aug. 2019.

Sartor, S., Caliari, V., Malinovski, L.I., Toaldo, I.M., and Bordignon-Luiz, M.T. (2017). Bioactive profiling of polyphenolics and oenological properties of red wines from Italian grapes (Vitis vinifera L.) cultivated in a selected subtropical region. Int. J. Food Prop. 20: 1319-1328.

Satisha, J., Somkuwar, R.G., Sharma, J., Upadhyay, A.K., and Adsule, P.G. (2010). Influence of rootstocks on growth yield and fruit composition of Thompson seedless grapes grown in the Pune region of India. S. Afr. J. Enol. Vitic. 31: 1-8.

Shahidi, F., and Ambigaipalan, P. (2015). Phenolics and polyphenolics in foods, beverages and spices: Antioxidant activity and health effectsA review. J. Funct. Foods 18: 820-897.

Singleton, V.L., and Rossi, J.A. (1965). Colorimetry of total phenolics with phosphomolybdic-phosphotungstic acid reagents. Am. J. Enol. Viticult. 16: 144-158.

Urvieta, R., Buscema, F., Bottini, R., Coste, B., and Fontana, A. (2018). Phenolic and sensory profiles discriminate geographical indications for Malbec wines from different regions of Mendoza, Argentina. Food chem. 265: 120-127.

Walker, R.R., Read, P.E., and Blackmore, D.H. (2000). Rootstock and salinity effects on rates of berry maturation, ion accumulation and colour development in Shiraz grapes. Aust. J. Grape Wine R. 6: 227-239.

Waterhouse, A.L. (2002). Determination of total phenolics. Current Protocols Food Anal. Chem. 6: I1-1. 